\title{
PELAYANAN LANJUT USIA TERLANTAR DALAM PANTI
}

\author{
Oleh \\ Sri Sulastri \& Sahadi Humaedi \\ ati.sukaati@gmail.com; Sahadi.humaedi@unpad.ac.id
}

\begin{abstract}
ABSTRAK
Jumlah penduduk lanjut usia (60 tahun keatas) akan terus meningkat. Peningkatan jumlah penduduk lanjut usia berhubungan positif dengan Ageing index dan sebaliknya berhubungan negatif dengan Potential Support Ratio. Jika pendapatan penduduk yang bekerja sebagai pendukung penduduk lansia tidak menunjukkan peningkatan berarti, maka jumlah penduduk lansia terlantar akan terus meningkat. Jumlah penduduk lansia wanita cenderung lebih banyak dan lebih rentan daripada pria karena tingkat partisipasi angkatan kerjanya rendah, lebih banyak yang berstatus lajang dan tinggal sendiri, dan berpendidikan rendah. Kebijakan perlindungan lansia saat ini lebih mengedepankan pelaksanaan kesejahteraan sosial dengan kelompok sasaran prioritas yaitu penduduk lansia terlantar. Kegiatan pelayanan lebih ditujukan untuk perlindungan dan rehabilitasi sosial, diantaranya melalui panti reguler. Dalam RPJMD 2015-2019 dikembangkan kebijakan Perawatan Jangka Panjang (Long-Term Care) yang dilaksanakan oleh 3 komponen utama yaitu pemerintah, masyarakat, dan rumah tangga. Pemerintah bertugas untuk menyediakan sistem asuransi LTC dan layanan berbasis institusi melalui panti; masyarakat menyediakan layanan berbasis komunitas, dan rumah tangga melaksanakan layanan berbasis rumah tangga. Tulisan ini ditujukan untuk mengidentifikasi masalah yang dihadapi penduduk lanjut usia dan pelayanan lanjut usia terlantar dalam panti. Dari hasil penelusuran beberapa literatur terkait diperoleh informasi bahwa Kelompok sasaran pelayanan sosial dalam panti, termasuk yang dikelola oleh pemerintah masih memilih lansia yang mampu mandiri dan memiliki keluarga, padahal mereka dapat dilayani melalui model layanan home care dan community care. Pelayanan dalam panti seyogyanya memilih lansia yang sudah tidak memiliki kemandirian yang tidak dapat ditangani oleh model pelayanan lain. Untuk itu, diperlukan pengembangan mekanisme penjangkauan lansia tersebut, proses pelayanan yang relevan, penyediaan sumberdaya manusia dan sarana pelayanan yang memadai.
\end{abstract}

Kata Kunci: Penduduk Lansia Terlantar; Pelayanan Berbasis Institusi; Perlindungan Sosial; Rehasilitasi Sosial; Long-Term Care.

\section{PENDAHULUAN}

Jumlah Penduduk berusia 60 tahun keatas atau biasa disebut sebagai penduduk lanjut usia (lansia), menurut data Sensus Penduduk tahun 2010 tercatat lebih dari 18,1 juta atau $7,6 \%$ dari total penduduk Indonesia.
Pada tahun 2025, jumlah penduduk lansia diproyeksikan akan berjumlah 33,7 juta atau sekitar 11,8\%; dan pada tahun 2035 akan mencapai 48,2 juta atau sekitar $15,8 \%$. Peningkatan penduduk lansia berkaitan dengan penurunan tingkat fertilitas dan penurunan 
angka kematian pada penduduk lansia. Peningkatan penduduk lansia berdampak pada Ageing Index yaitu ratio penduduk lansia dibandingkan dengan 100 orang penduduk usia 0-14 tahun; yang menunjukkan keseimbangan antara penduduk tua dengan anak-anak. Selama periode 2010-2035 Ageing Index mengalami peningkatan dari 26,3 pada tahun 2010 menjadi 73,4 pada tahun 2035. Kondisi ini akan menyebabkan penurunan pada Potential Support Ratio yaitu rata-rata jumlah penduduk yang memiliki potensi untuk memberikan dukungan (penduduk yang bekerja) untuk setiap satu orang penduduk lansia. Potential Support Ratio tahun 2010 menunjukkan angka 13 pekerja per satu orang penduduk lansia dan tahun 2035 menurun menjadi 6,4 pekerja (UNFPA Indonesia, 2014). Jika pada tahun 2035 pendapatan penduduk yang bekerja tidak menunjukkan peningkatan berarti, maka terdapat kecenderungan meningkatnya penduduk lansia terlantar yang tidak mendapat dukungan untuk memenuhi kebutuhan dasar mereka.

Penduduk lansia wanita cenderung lebih banyak daripada pria, terutama di usia 70 tahun keatas. Mereka juga lebih rentan; setidaknya dilihat dari empat indikasi berikut: 1) tingkat partisipasi angkatan kerja lebih rendah (wanita $35,3 \%$ dan pria $69,9 \%$ ), 2) proporsi yang berstatus tidak memiliki pasangan lebih tinggi (wanita $60,9 \%$ dan pria $15,9 \%$ ), 3) wanita lebih banyak yang tinggal sediri (wanita 14,6\% dan pria $4,2 \%$ ); dan 4) pendidikan mereka lebih rendah daripada pria, pendidikan lansia wanita $39,1 \%$ tidak pernah sekolah, 19,8\% tidak tamat SD, dan $31 \%$ tamat SD.

Dalam UU No. 13 tahun 1998 dan Permensos No. 19 tahun 2012, penduduk lansia dikelompokkan dalam 2 kategori yaitu Lanjut Usia Terlantar dan Lanjut Usia Potensial. Lanjut Usia Telantar adalah seseorang yang berusia 60 (enam puluh) tahun atau lebih dan karena faktor-faktor tertentu tidak dapat memenuhi kebutuhan dasarnya; sementara itu Lanjut Usia Potensial adalah penduduk lansia yang masih mampu melakukan pekerjaan dan/atau kegiatan yang dapat menghasilkan barang dan/atau jasa.
Penduduk lansia terlantar dianggap sebagai penyandang masalah kesejahteraan sosial (PMKS), karena mereka memiliki kehidupan yang tidak layak secara kemanusiaan dan memiliki kriteria masalah sosial diantaranya kemiskinan dan ketelantaran. Mereka tidak terpenuhi kebutuhan dasarnya seperti sandang, pangan, dan papan; dan terlantar secara psikis, dan sosial (Lampiran Permensos No. 08 Tahun 2012).

Pada tahun 2014 Menteri Sosial menyebutkan bahwa jumlah penduduk lansia terlantar sekitar 2.851.606 orang. Keberadaan penduduk lansia terlantar mencerminkan bahwa keluarga sebagai lingkungan terdekat para lansia tidak dapat memberikan dukungan sosial dengan baik. Terdapat beberapa alasan keluarga tidak dapat memberi dukungan sosial bagi lansia, diantaranya adalah: 1) kemiskinan, keluarga tidak dapat memberikan dukungan instrumental karena mereka miskin sehingga tidak mampu memberikan kebutuhan dasar pada anggota keluarganya yang sudah lansia; 2) nilai-nilai kekeluargaan sudah mulai melemah, lansia dianggap sebagai beban keluarga, keluarga cenderung memperhatikan keluarga intinya tanpa memperhatikan kebutuhan keluarga besarnya; 3) kesibukan karena bekerja, anak-anak memiliki pekerjaan yang menuntut curahan waktu yang banyak, sehingga mereka tidak memiliki waktu yang cukup untuk merawat orangtua; 4) tidak mampu merawat, banyak diantara keluarga yang tidak memiliki kemampuan untuk merawat karena lansia di keluarganya memerlukan perawatan khusus. Tiga alasan terakhir yang menyebabkan lansia terlantar, tidak hanya dapat terjadi pada keluarga miskin tetapi juga dapat terjadi pada keluarga kalangan menengah dan atas, dimana terdapat lansia yang tidak terlantar secara ekonomi tetapi terlantar secara psikis dan sosial.

Permensos No. 19 tahun 2012 menyebutkan bahwa pelayanan sosial lanjut usia dapat dilakukan baik di dalam panti maupun di luar panti; dan dapat dilakukan baik oleh pemerintah, pemerintahan daerah provinsi, pemerintahan daerah kabupaten/kota, 
maupun masyarakat. Kebijakan untuk penduduk lansia saat ini lebih mengedepankan pelaksanaan kesejahteraan sosial dengan kelompok sasaran prioritas yaitu penduduk lansia terlantar yang karena faktor-faktor tertentu tidak dapat memenuhi kebutuhan dasar baik jasmani, rohani maupun sosial. Kegiatan yang utama lebih ditujukan untuk perlindungan dan rehabilitasi sosial, seperti: 1) panti reguler, yang memberikan pelayanan untuk memenuhi kebutuhan dasar bagi lansia yang tinggal di panti; 2) Day Care untuk kegiatan dan aktualisasi lansia yang tinggal sendiri atau tinggal bersama keluarga melalui pelayanan panti atau Dinas Sosial; 3) Home Care untuk pemenuhan kebutuhan dasar dan pendampingan lansia terlantar atau hidup sendiri di rumah dengan melakukan 2-3 kali kunjungan per minggu oleh pekerja sosial; 4) Kelompok Usaha Bersama (KUBe) atau Usaha Ekonomi Produktif (UEP) untuk peningkatan penghasilan dan pendapatan lanjut usia yang masih dapat produktif; dan 5) Asistensi Sosial untuk Lanjut Usia Terlantar (ASLUT) dengan memberikan bantuan sosial Rp 300.000,- per bulan), dalam kegiatan ini dimungkinkan partisipasi masyarakat setempat untuk lansia terlantar (Kementerian PPN dan Bappenas, 2015).

Arah kebijakan lanjut usia dalam Rancangan Pembangunan Jangka Menengah Nasional (RPJMN) 2015-2019 diantaranya adalah memperkuat skema perlindungan bagi penduduk lansia. Perlindungan penduduk lansia akan lebih diarahkan pada penyediaan layanan Long Term Care (LTC). Layanan Long Term Care bagi lansia dianggap perlu lebih mendapat perhatian karena para lansia mengalami kondisi kronis, penurunan fungsional, dan keterbatasan dalam melakukan aktivitas sehari-hari (Activities of Daily Living atau ADL), sehingga mereka memiliki ketergantungan tinggi. Layanan LTC melibatkan tiga komponen, yaitu pemerintah berupa penyediaan sistem asuransi LTC dan layanan berbasis institusi (institutional based); masyarakat menyediakan layanan berbasis komunitas (Community based); dan rumah tangga akan mendapatkan layanan penguatan kapasitas rumah tangga agar dapat melakukan pelayanan kepada lansia menggunakan layanan berbasis rumahtangga (Home-Based) (Kementerian PPN dan Bappenas, 2015).

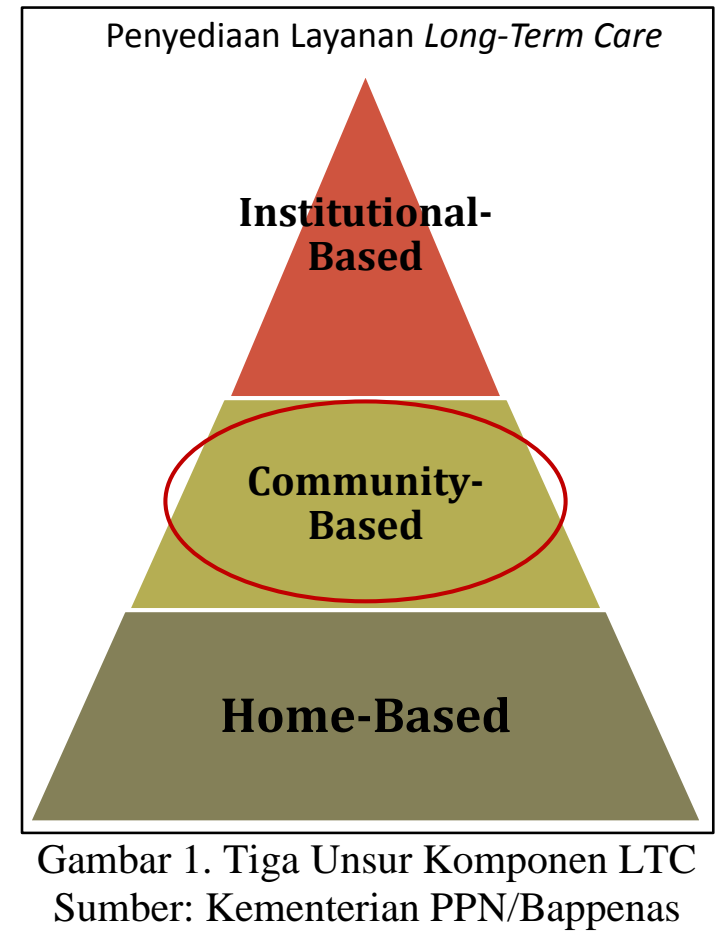

Model layanan berbasis institusi atau panti proporsinya sangat kecil, dan pelayanan LTC lebih difokuskan pada layanan berbasis komunitas (Kementerian PPN/Bappenas, 2015). Tulisan ini menyajikan permasalahan yang dihadapi penduduk lansia terlantar, kebutuhan pelayanan bagi mereka, dan pelayanan sosial bagi penduduk lansia terlantar yang ada saat ini.

\section{METODA}

Untuk mengidentifikasi permasalahan penduduk lansia, kebutuhan pelayanan, dan pelayanan sosial dalam panti, dilakukan kajian literatur baik berupa buku, artikel, publikasi online, hasil-hasil kajian pelayanan PMKS lansia terlantar di panti, dan peraturan perundang-undangan terkait. Selain itu, dilakukan pula wawancara dengan pengelola panti werdha. Selanjutnya data yang terkumpul dianalisis secara kualitatif sehingga permasalahan, kebutuhan pelayanan, serta pelayanan sosial yang saat ini dilakukan oleh panti dapat teridentifikasi; dan selanjutnya 
dapat merumuskan pengembangan pelayanan bagi penduduk lansia terlantar dalam panti yang diperlukan.

\section{HASIL DAN PEMBAHASAN}

\section{a. Masalah Penduduk Lanjut Usia}

Lanjut usia merupakan tahap terakhir dalam kehidupan manusia, setelah melalui tahap bayi, anak-anak, remaja, dan dewasa. Pada setiap tahapan kehidupan, seseorang menemukan dirinya dalam situasi dan menghadapi masalah yang berbeda. Masalah yang dihadapi lansia dapat dibagi ke dalam 5 aspek yaitu masalah fisiologis, sosial, finansial, emosional, dan psikologis. Kelima aspek masalah tersebut saling terkait satu sama lain (Suani, melalui http://www.yourarticlelibrary.com/india2/top-5-problems-faced-in-old-age/47679/).

Masalah fisiologis yang dihadapi lansia terkait dengan penurunan kemampuan organ tubuh. Telah ditemukan bahwa kemampuan fungsional organ tubuh sebagian besar manusia menunjukkan penurunan $0,8-1 \%$ per tahun setelah menginjak usia 30 tahun. Penurunan tersebut merupakan kejadian normal, disebabkan karena penyakit, stress, status pekerjaan, status nutrisi, dan faktorfaktor lingkungan. Perubahan fisik utama pada lansia adalah perubahan eksternal, internal, dan perubahan kapasitas pancaindera (Adulthood and Ageing melalui http://download.nos.org/srsec328newE/328E L14.pdf). Penurunan kemampuan organ tubuh tersebut dapat mempengaruhi status gizi dan fungsi otak; yang selanjutnya akan berpengaruh pada risiko mengidap penyakit kronis dan penurunan sistem imunitas yang menyebabkan kualitas hidup lansia terganggu. (Anandati, melalui https://anandati.wordpress.com/2015/02/07/m asalah-kesehatan-pada-lansia/).

Penduduk lansia juga rentan pengalami masalah relasi dengan lingkungan sosialnya. Terkait dengan perubahan pada kondisi fisik internal dan pancaindera, lansia juga dapat mengalami penurunan kapasitas kognisi.
Kognisi didefinisikan sebagai proses dimana informasi diperoleh, disimpan, dan digunakan. Penurunan kapasitas kognisi dapat berpengaruh pada daya ingat, proses belajar, kecepatan kinerja, perhatian atau daya konsentrasi, dan daya tanggap pada lingkungan sosial. Orang-orang berusia lanjut sering melaporkan lupa dan kesulitan dalam belajar teknik dan keterampilan baru. Daya konsentrasi dan daya tanggap pada stimulus lingkungan akan berkonsekuensi sangat besar pada kehidupan sosial. Banyak lansia yang menarik diri secara perlahan dari masyarakat, mengurangi hubungan emosional dengan orang lain, dan menunjukkan penurunan ketertarikan terhadap berbagai persoalan kemasyarakatan. Pemisahan diri dari lingkungan sosialnya, secara timbal balik akan menyebabkan masyarakat juga menjauh dari mereka. Kehidupan sosial mereka dipersempit oleh hilangnya pekerjaan, kematian kerabat dan pasangan, dan kondisi fisik yang lemah yang membatasi partisipasi mereka dalam kehidupan sosial. Selain itu, saat ini relatif banyak lansia yang mengalami masalah relasi sosial dengan anak dan sanak keluarga yang sibuk bekerja, sehingga seharian ia harus hidup dengan pembantu, atau seharian hanya bercanda dengan hewan peliharaan; tidak jarang yang hidup dalam keluarga dengan tensi emosi tinggi, kerap dibentak-bentak atau dipukul, dan perlakuan kasar lainnya (Aji, 2013).

Di sisi lain penduduk lansia juga dapat mengalami masalah finansial. Seiring dengan berkurangnya kemampuan untuk melakukan kegiatan produktif, lansia yang sudah tidak bekerja lagi atau sudah melewati masa pensiun, pendapatan mereka akan berkurang. Sementara itu, biaya hidup mereka biasanya meningkat karena tidak hanya untuk kebutuhan sehari-hari tetapi juga untuk kebutuhan perawatan jika mereka sakit. Dengan berkurangnya pendapatan, kedudukan mereka akan beralih dari orang yang "berpenghasilan" menjadi orang yang "tergantung". 


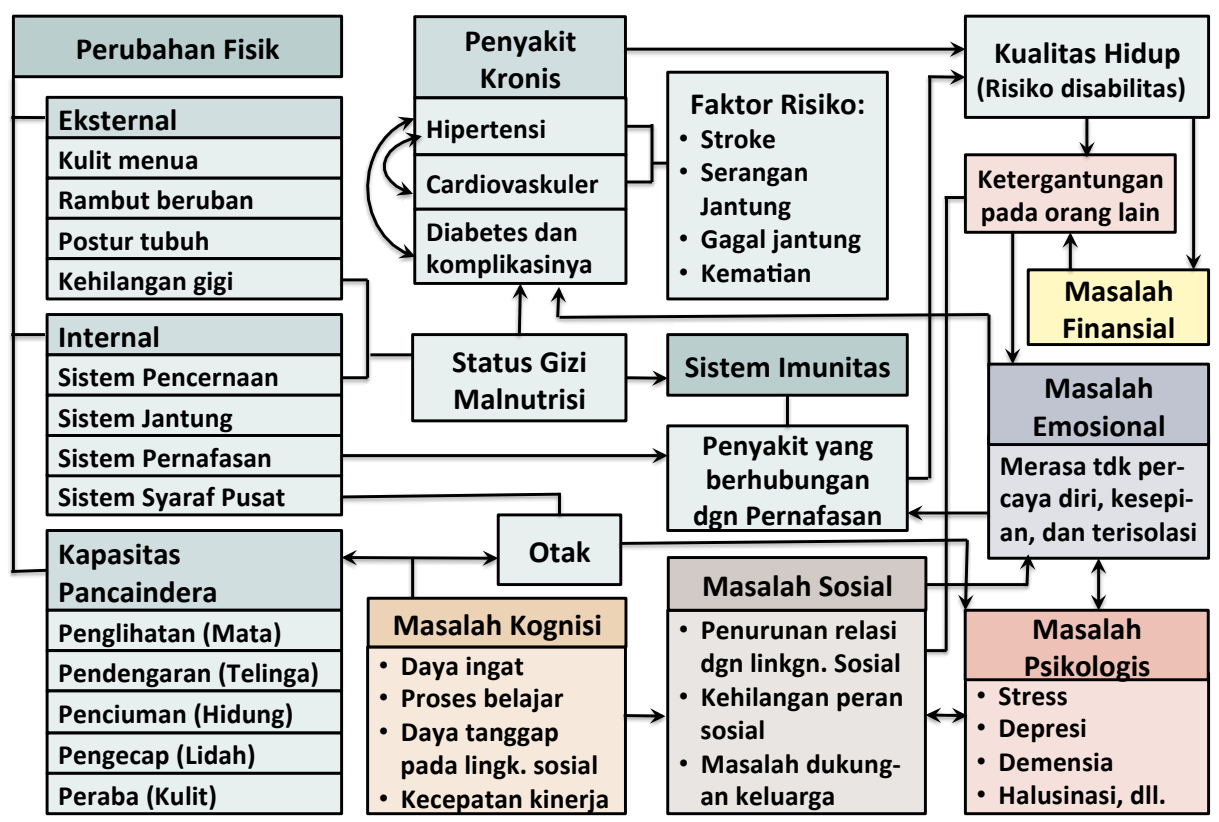

Gambar 2. Kompleksitas Masalah pada Lansia

Penurunan fungsi fisik yang dapat menjadi faktor risiko pada disabilitas dan masalah finansial dapat menyebabkan lansia memiliki ketergantungan tinggi pada orang lain, jika relasi dengan lingkungan sosialnya kurang menguntungkan maka akan menimbulkan masalah emosional seperti merasa kurang berharga, tidak percaya diri, kesepian, dan terisolasi yang berpotensi menjadi masalah psikologis yang lebih berat (Gambar 2)

Secara individual tentu masalah yang dihadapi lansia berbeda-beda. Perubahan fisiologis pada lansia sangat tergantung pada perilaku sehat, umur kronologis, kondisi biologis, lingkungan fisik, lingkungan sosial, dan kondisi psikologis (kepribadian) pada fase kehidupan sebelumnya. Dalam menghadapi kondisi masalah yang sama pun, setiap lansia menghadapinya secara berbeda, tergantung pada cara pandang dan cara menyikapinya, atau kepribadiannya. Kepribadian adalah semua corak perilaku dan kebiasaan individu yang terhimpun dalam dirinya dan digunakan untuk bereaksi serta menyesuaikan diri terhadap segala rangsangan baik dari luar maupun dari dalam. Corak perilaku dan kebiasaan ini merupakan kesatuan fungsional yang khas pada seseorang. Kepribadian manusia yang sudah terbentuk sebelum masa lansia dan bersifat dinamis dapat berkontribusi dalam menghadapi permasalahan ketika lansia.

Dr. Nasreen Khatri, seorang ahli psikologi klinis menyebutkan bahwa setiap orang memiliki kepribadian campuran, tetapi ini penting untuk mengoptimalkan gaya hidup yang sehat dan menyenangkan. Sifat kepribadian yang bermanfaat tersebut meliputi: 1) resilien (resillience) atau kemampuan untuk beradaptasi; 2) otonomi (autonomy), memiliki perasaan tidak tergantung; 3) integrasi sosial (social integration), perasaan termasuk dalam atau menjadi bagian dari komunitas dan masyarakat secara luas; 4) integritas (integrity), perasaan memiliki kehidupan yang berarti; dan 5) kearifan (wisdom), perasaan memiliki pandangan dan pengalaman yang bernilai untuk dibagikan kepada orang lain (Baycrest, melalui http://www.baycrest.org/smartaging/personality-and-successful-aging/).

Aspek-aspek kepribadian ini yang perlu terus dikembangkan agar seseorang dapat memiliki ketahanan psikologis dalam menghadapi masa lansia. Pada lansia, kepribadiannya dapat berfungsi dengan baik, kecuali kalau mereka mengalami gangguan kesehatan jiwa atau tergolong patologik. 


\section{b. Pelayanan Sosial bagi Lansia dalam Panti saat ini}

Merujuk pada masalah dan kebutuhan yang dihadapi lansia yang telah dipaparkan sebelumnya, lansia memerlukan pelayanan yang terkait dengan masalah dan kebutuhan mereka, meliputi: pelayanan dasar, pelayanan kesehatan, pelayanan yang terkait dengan kondisi sosial, emosional, psikologis, dan finansial. Jika merujuk pada Peraturan Menteri Sosial No. 19 tahun 2012 tentang Pedoman Pelayanan Sosial Lanjut Usia, pada pasal 7 tercantum bahwa pelayanan dalam panti dilakukan dengan tujuan untuk meningkatkan kualitas hidup, kesejahteraan, dan terpenuhinya kebutuhan dasar lanjut usia. Adapun jenis pelayanan yang diberikan dalam panti, meliputi: 1) pemberian tempat tinggal yang layak; 2) jaminan hidup berupa makan, pakaian, pemeliharaan kesehatan; 3) pengisian waktu luang termasuk rekreasi; 4) bmbingan mental, sosial, keterampilan, agama; dan 5) pengurusan pemakaman atau sebutan lain.

1) Tempat tinggal yang layak bagi lansia adalah yang bersih, sehat, aman, nyaman, dan memiliki akses yang mudah pada fasilitas yang dibutuhkan lansia, sehingga dengan kondisi kemampuan fisiknya yang makin menurun masih memungkinkan dapat menjalankan aktivitas sehari-hari dengan mudah, aman, dan tidak sangat tergantung pada orang lain. Umumnya lanjut usia dihadapkan pada masalah hunian sebagai berikut: lokasi kamar yang berjauhan dengan lokasi kamar mandi, keadaan kamar mandi yang kurang mendukung, penggunaan tangga, permukaan lantai yang tidak rata, dan alur sirkulasi hunian terhadap fasilitas lingkungan kurang menunjang. Tempat tinggal yang layak bagi lansia adalah yang lapang atau barrier free. Hal ini sangat bermanfaat bagi lansia, terutama dalam pergerakan atau aksesibilitas dalam rumah, bahkan ketika mereka harus menggunakan kursi roda. Kurniadi (2012) merinci karakterik rumah yang ramah lansia, secara garis besar, terbebas dari tangga dan lantai yang tidak rata atau licin, pencahayaan yang baik, kamar mandi dekat dengan kamar dan memungkinkan kursi roda dapat masuk, dan aman karena mereka kurang mampu melindungi dirinya terhadap bahaya. Di negara-negara maju, pelayanan kelompok lanjut usia dilakukan dalam ruangan khusus, bahkan rumah sakit khusus dan perkampungan khusus. Adanya fasilitas tersebut ditujukan untuk memberi lingkungan kehidupan yang nyaman dan sesuai bagi kelompok lanjut usia (Wijayanti, 2008). Kondisi hunian di dalam panti pun seyogyanya memperhatikan kebutuhan lansia tersebut.

2) Para lansia seyogyanya mendapatkan makanan yang sesuai dengan kondisi kesehatannya. Oleh karena itu, makanan untuk lansia sebaiknya dikontrol atas rekomendasi ahli gizi. Ahli gizi perlu berkerjasama dengan dokter untuk mengetahui kondisi kesehatan lansia atau jenis penyakit yang diderita, untuk menentukan apa yang boleh atau tidak boleh dimakan. Dengan demikian, makanan untuk masing-masing lansia kemungkinan berbeda dengan cara mengolah yang berbeda pula. Pakaian yang digunakan sebaiknya bersih, layak dan nyaman dipakai. Untuk pemeliharaan kesehatan seyogyanya terdapat fasilitas kesehatan berupa poliklinik yang buka 24 jam dan memberikan pelayanan kegawatdaruratan yang mudah diakses. Apabila perlu dirujuk, tersedia fasilitas ambulans yang siap setiap saat. Biasanya diperlukan pula fasilitas fisioterapi.

3) Pemanfaatan waktu luang merupakan suatu upaya untuk memberikan peluang dan kesempatan bagi lansia untuk mengisi waktu luangnya dengan berbagai kegiatan atau aktivitas yang positif, bermakna, dan produktif bagi dirinya maupun orang lain. Kegiatan-kegiatan yang mereka lakukan harus sesuai dengan minat, bakat, dan potensi yang mereka miliki (Annubawati, 2014). Tidak hanya sekedar mengisi waktu luang tetapi sesuatu yang menyenangkan, akan lebih baik jika produktif; sehingga dapat berfungsi sebagai terapi masalah 
psikososial dan emosional yang mungkin dialami oleh lansia. Demikian juga dengan kegiatan rekreasi, seyogyanya tidak hanya menyenangkan tetapi merupakan kesempatan untuk berinteraksi dengan lingkungan di luar panti sehingga mereka merasa tidak terisolasi tetapi masih terhubung dengan lingkungan di sekitarnya.

4) Bimbingan mental dan agama lebih ditujukan untuk mengatasi masalah emosional dan psikologis. Berdasarkan informasi dari Tim Kajian Bentuk Pelayanan Lanjut Usia di Daerah Istimewa Yogyakarta, banyak lansia yang tinggal di panti werdha yang kesepian, sedih, menarik diri dari pergaulan dan kegiatan, pasif, murung, mengalami emosi negatif, bermusuhan dengan sesama penghuni panti, dan sebagainya. Untuk membantu mengatasi masalah tersebut kegiatan bimbingan mental dan keagamaan melalui kegiatan konseling dapat membantu mereka. Sementara itu, bimbingan sosial lebih ditujukan untuk mengatasi masalah relasi sosial dengan keluarga atau lingkungan sosialnya. Terkait dengan pelaksanaan bimbingan sosial di panti wedha, Tim Kajian Bentuk Pelayanan Lansia di DIY (2014) menemukan bahwa di panti werdha ada kecenderungan pelayanan bimbingan sosial ini relatif sama dengan bimbingan psikologis; belum diarahkan untuk memfasilitasi interaksi atau komunikasi antar penghuni panti sosial maupun dengan warga masyarakat lainnya. Masalah relasi sosial seringkali menjadi penyebab atau saling pengaruh mempengaruhi dengan masalah emosional dan psikologis, sehingga memperbaiki relasi sosial dengan keluarga atau lingkungan sosial lainnya akan membantu memecahkan masalah emosional dan psikologis juga.

5) Pelayanan bagi lansia dalam panti diberikan sampai dengan lansia meninggal. Pelayanan yang diberikan merupakan perawatan jangka panjang (Long-Term Care). Oleh karena itu, pelayanan pengurusan pemakaman pun turut menjadi tanggung jawab panti, sesuai dengan agama yang dianutnya masing-masing.

Oleh karena jenis-jenis pelayanan tersebut merupakan jenis pelayanan yang tercantum dalam Pedoman Pelayanan Sosial Lanjut Usia (Permensos No. 19 tahun 2012) maka di setiap panti werdha, terutama yang dikelola oleh pemerintah, maka tampaknya jenis layanan yang diberikan pada lansia relatif sama, karena semua merujuk pada pedoman tersebut. Sebagai contoh misalnya jenis pelayanan di Panti Sosial Tresna Werdha (PSTW) Budhi Dharma Bekasi yang merupakan Unit Pelaksana Teknis di lingkungan Kementerian Sosial RI; sebagaimana tercantum dalam website resminya, jenis pelayanan yang diberikan meliputi: 1) Penyediaan tempat yang sehat aman dan nyaman berupa tempat istirahat/ tidur dan tempat beraktivitas; 2) Pelayanan fisik dan kesehatan meliputi makan dengan gizi seimbang, pemeriksaan kesehatan, dan pelayanan kebugaran; 3) Pelayanan sosial berupa bimbingan mental, sosial, dan konsultasi; 4) Pelayanan kerohanian seperti sholat berjamaah, pengajian, ceramah agama bagi yang beragama Islam dan kebaktian bagi yang beragama kristen; 5) Pelayanan rekreasi dan penyaluran hobi meliputi darmawisata, hiburan (menyanyi, menari dll.), mengadakan perayaan-perayaan, perpustakaan, pemberian bimbingan keterampilan/kerajinan tangan; 6) Pelayanan pendampingan dalam pemenuhan kebutuhan harian dan pendampingan aktivitas; 7) Pelayanan data dan informasi. Demikian juga di Balai Perlindungan Sosial Tresna Wherda (BPSTW) Ciparay yang merupakan UPT Kanwil Kementerian Sosial Provinsi Jawa Barat; dan di PSTW di DI Yogyakarta.

Walaupun jenis pelayanannya relatif sama namun kelompok sasaran panti-panti sosial yang dikelola oleh pemerintah ternyata ada perbedaan. PSTW Budhi Dharma Bekasi menerapkan Program Subsidi Silang. Kelompok sasaran yang dilayani tidak hanya lanjut usia terlantar yang selama ini sudah ditampung di panti ini, tetapi juga menampung lanjut usia dari keluarga mampu. Penerapan program subsidi silang tersebut dilakukan 
untuk merespons berbagai kebutuhan dan permasalahan semua lanjut usia. Lansia dari kalangan keluarga tidak mampu, adalah lansia yang benar-benar terlantar tidak memiliki keluarga yang bertanggung jawab; sementara lansia dari keluarga yang mampu secara ekonomi adalah yang masih memiliki keluarga yang bertanggung jawab. Di BPSTW Ciparay Kabupaten Bandung, tidak menggunakan sistem subsidi silang, semua fasilitas yang diberikan pada lansia dibiayai oleh dana APBD Provinsi Jawa Barat. Tidak ada dana yang diperoleh dari lansia yang mendapat pelayanan. BPSTW Ciparay tidak menyebutkan persyaratan bahwa lansia harus yang tidak memiliki keluarga tetapi harus yang tidak mampu secara ekonomi. PSTW di DIY menerapkan sistem pelayanan yang sama dengan BSTW Ciparay, tetapi menyebutkan dengan jelas bahwa kelompok sasarannya lansia yang tidak punya keluarga; walaupun dalam kenyataannya sebagian besar masih memiliki keluarga.

Kriteria lansia sasaran layanan yang sama di ketiga lembaga pelayanan tersebut adalah 'masih dapat mengurus dirinya sendiri atau masih mandiri'. Persyaratan tersebut dapat membatasi akses bagi lanjut usia yang sudah tidak mampu mandiri dan banyak tergantung pada bantuan orang lain, yang justru lebih membutuhkan perlindungan dan pelayanan dari negara. Jika merujuk pada konsep pelayanan sosial dalam konteks kebijakan publik bahwa negara seyogyanya memfokuskan pada kelompok-kelompok yang lemah (Suharto, 2007:5). Walaupun klien lanjut usia berasal dari keluarga miskin, jika masih mandiri dan ada/tidak ada keluarganya maka mereka masih dapat dilayani dengan model pelayanan di luar panti, yaitu home care dan community care. Dalam hal ini tentu keluarga harus mendapatkan pelayanan peningkatan kapasitas dalam merawat lansia. Panti yang dikelola oleh pemerintah seyogyanya diperuntukkan bagi lanjut usia yang memang benar-benar terlantar dan tidak mandiri. Merujuk pada kebijakan tentang layanan Long-Term Care (LTC), bahwa salah satu komponen LTC adalah pemerintah; tugas pemerintah adalah menyediakan sistem asuransi LTC dan layanan berbasis institusi (institutional based). Porsi layanan berbasis institusi paling kecil dibandingkan dengan yang berbasis keluarga dan komunitas; oleh karena itu kelompok sasaran layanan harus ditentukan lebih selektif, lebih mengutamakan pada lansia yang tidak memungkinkan dilayani melalui rumahtangga atau komunitas.

\section{c. Kebutuhan Pengembangan Proses Pelayanan}

Merujuk pada masalah yang umumnya dihadapi penduduk lansia; jenis dan mekanisme layanan yang diterapkan saat ini di panti werdha, terutama yang dikelola oleh pemerintah; kebijakan perlindungan lansia; dan tanggungjawab negara/pemerintah dalam pelaksanaan perlindungan sosial bagi lansia; yang perlu ditinjau kembali dalam proses pelayanan adalah kriteria kelompok sasaran pelayanan. Perlu ditentukan dengan tegas kriteria lansia yang paling tepat untuk dilayani di panti sosial atau layanan berbasis institusi (institutional based). Terutama pada panti werdha yang dikelola oleh pemerintah, seyogyanya memfokuskan pada lansia yang mengalami tingkat kerentanan dan keterlantaran sangat tinggi; yaitu lansia yang sudah tidak mememiliki kemandirian yang tidak mungkin dilayani melalui pelayanan sosial berbasis rumah tangga dan berbasis komunitas. Lansia dalam kondisi seperti itu, tidak selalu berhubungan dengan umur kronologis mereka. Ada kemungkinan, usianya masih 60 tahunan tetapi kondisi fisiknya memiliki tingkat kerentanan tinggi dan sepenuhnya tergantung pada orang lain. Mereka juga seyogyanya yang tidak memiliki keluarga yang dapat merawatnya. Penentuan kelompok sasaran yang sudah tidak memiliki kemandirian akan berkonsekuensi pada proses penjangkauan kelompok sasaran, proses pelayanan, penyediaan sumberdaya manusia, dan sarana pelayanan.

Untuk mendapatkan klien lansia tersebut dapat merujuk pada hasil pendataan PMKS lansia terlantar yang saat ini sudah dilakukan. Kriteria lansia terlantar menurut Permensos 
No. 08 tahun 2012 adalah: seseorang yang berusia 60 tahun atau lebih yang tidak terpenuhi kebutuhan dasar seperti sandang, pangan, dan papan; dan terlantar secara psikis, dan sosial. Dengan menggunakan kriteria tersebut, informasi tentang tingkat kemandirian tampaknya tidak terdapat pada hasil pendataan ini. Untuk itu diperlukan pengembangan proses pengumpulan data dengan melakukan penelusuran lebih lanjut terkait dengan tingkat kemandirian lansia. Dalam pelaksanaannya dapat bekerja sama dengan Kelompok Dasa Wisma, Kader Posbindu di tingkat RW yang dibina oleh Tim Penggerak PKK. Langkah ini sejalan dengan pemikiran pengembangan kebijakan kelanjutusiaan di masa datang yang dicanangkan oleh Kementerian PPN dan Bappenas yaitu penguatan database dan registrasi lansia.

Untuk lansia yang sudah tidak memiliki kemandirian, diperlukan pelayanan yang lebih intensif terutama dalam tahap assessment agar diperoleh informasi secara menyeluruh tentang masalah biopsikososial yang dihadapi oleh lansia. Untuk itu diperlukan tenaga pelayanan profesional seperti dokter spesialis geriatri untuk mengidentifikasi kondisi kesehatan; psikolog atau psikiater untuk mengidentifikasi kondisi emosional dan psikologis; dan pekerja sosial untuk mengidentifikasi masalah terkait interaksi sosial dengan lingkungannya. Dalam tahap treatment besar kemungkinan setiap jenis layanan harus diberikan secara individual, karena masalah yang dihadapi lansia kemungkinan berbeda-beda. Oleh karenanya, jumlah tenaga pelayanan yang diperlukan akan lebih banyak, terutama untuk perawatan kesehatan dan bantuan untuk kegiatan sehari-hari, seperti tenaga perawat kesehatan dan pramu werdha; dan sebaiknya tinggal di sekitar panti. Rohaniwan, ahli gizi, dan ahli fisioterapi sangat diperlukan. Prasarana sarana dan sarana pelayanan pun kemungkinan berbeda dengan yang diperlukan oleh lansia yang masih mampu mandiri; mulai dari gedung, perlengkapan di kamar, dan sebagainya perlu disesuaikan dengan kebutuhan lansia terkait dengan ketidakmandiriannya.

\section{SIMPULAN}

Pelayanan berbasis institusi atau pelayanan yang diselenggarakan dalam panti sosial merupakan salah satu alternatif model pelayanan bagi lansia terlantar, selain pelayanan yang berbasis keluarga dan komunitas. Pemerintah memiliki tanggung jawab utama untuk menyelenggarakan model pelayanan tersebut. Untuk itu, pemerintah seyogyanya menyasar kelompok sasaran yang tidak mungkin dilayani oleh model pelayanan lainnya, agar tidak terjadi tumpang-tindih seperti yang dilaksanakan saat ini. Lansia terlantar yang sudah tidak memiliki kemandirian merupakan kelompok sasaran yang tepat sesuai dengan mandat yang dibebankan kepadanya, yakni memberikan pelayanan kepada kelompok masyarakat yang paling lemah. Terkait dengan kelompok sasaran tersebut, terdapat konsekuensi pada mekanisme penjangkauan kelompok sasaran, proses pelayanan, serta penyediaan sumberdaya yang berkualitas dan prasarana dan sarana yang memadai.

\section{DAFTAR PUSTAKA}

"Adulthood and Ageing" Modul III Developmental Processes. Melalui http://download.nos.org/srsec328newE/ 328EL14.pdf (15-08-2016)

Aji. S. Orangtua Tinggal di Panti Jompo? Mengapa Tidak!. Pondok Lansia Berdikari-Panti Werdha. Melalui https://www.facebook.com/permalink.p hp? story fbid=501014353302746\&id=4 53634871374028 (15-08-2016)

Anandati. Masalah Kesehatan Pada Lansia. melalui

https://anandati.wordpress.com/2015/02 /07/masalah-kesehatan-pada-lansia/)

Annubawati, E.A. 2014. Pengisian Waktu Luang bagi Lanjut Usia dengan Bimbingan Keterampilan. Melalui http://budhidharma.kemsos.go.id/modul es.php? name $=$ News \&file $=$ article $\&$ sid $=1$ $\underline{73}(15-08-2016)$ 
Baycrest, Personality And Successful Aging. Melalui http://www.baycrest.org/smartaging/personality-and-successfulaging/) (10-08-2016)

Dinas Sosial Provinsi Jawa Barat. Balai Perlindungan Sosial Tresna Werdha Ciparay. Melalui http://dissos.jabarprov.go.id/current.php ?submenuheader $=2 \&$ sel $=$ oth $\& \mathrm{idx}=725$ (10-08-2016)

Interdisciplinary Islamic Studies Kesejahteraan Sosial Program Pascasarjana UIN Sunan Kalijaga. 2014. Bentuk Pelayanan Lanjut Usia Daerah Istimewa Yogyakarta. Melalui https://www.scribd.com/doc/244533996 /KAJIAN-Bentuk-Pelayanan-BagiLanjut-Usia

Kartinah, Sudaryanto, A. 2008. "Masalah Psikososial Pada Lanjut Usia”. Berita Ilmu Keperawatan Vol. I. No.1., Juni 2008 hlm. 93-96. Melalui

https://publikasiilmiah.ums.ac.id/bitstre am/handle/11617/486/2h.pdf?sequence $=1$ (10-08-2016)

Kementerian Sosial. Profil Panti Sosial Tresna Werdha Budhi Dharma. Melalui http://budhidharma.kemsos.go.id/modul es.php?name $=$ Content $\&$ pa $=$ showpage $\&$ pid=25. $(10-8-2016)$

Keputusan Menteri Sosial Nomor 93/HUK/1999 tentang Uraian Tugas Pejabat Fungsional Pekerja Sosial di Lingkungan Panti Sosial

Kementerian PPN/Bappenas. 2015. Perlindungan Sosial Lanjut Usia. Jakarta: Direktorat Perlindungan Sosial dan Kesejahteraan Masyarakat. melalui http://cas.ui.ac.id/wpcontent/uploads/seminar27052015/Perlindungan-SosialLANSIA-CAS.pdf (10-08-2016)

Peraturan Menteri Sosial No. 08 Tahun 2012 Tentang Pedoman Pendataan dan Pengelolaan Data Penyandang Masalah
Kesejahteraan Sosial dan Potensi dan Sumber Kesejahteraan Sosial.

Peraturan Menteri Sosial No. 19 tahun 2012 Tentang Pedoman Pelayanan Sosial Lanjut Usia

Peraturan Pemerintah Nomor 43 Tahun 2004 tentang Pelaksanaan Upaya Peningkatan Kesejahteraan Sosial Lanjut Usia ( Lansia)

Scheibe, S., \& Carstensen, L.L. 2010. "Emotional aging: recent findings and future trends". Journal of Gerontology: Psychological Sciences, 65B(2), 135144, doi:10.1093/geronb/gbp132. Advance Access publication on January 6, 2010.

Shuani. Top 5 Problems Faced in Old Age. Melalui http://www.yourarticlelibrary.com/india -2/top-5-problems-faced-in-oldage/47679/

Suharto, E. Meretas Kebijakan Sosial Pro Poor: Menggagas Pelayanan Sosial yang Berkeadilan. Melalui http://www.policy.hu/suharto/Naskah\% 20PDF/UGMPelayananSosial.pdf (1508-2015)

Tira. 2009. Panti Sosial Subsidi Silang. Melalui https://rehsos.kemsos.go.id/modules.ph $\mathrm{p}$ ? name $=$ News $\&$ file $=$ article $\&$ sid $=422$ (10-08-2016)

Wijayanti, 2008. "Hubungan Kondisi Fisik RTT Lansia Terhadap Kondisi Sosial Lansia di RW 03 RT 05 Kelurahan Tegalsari, Kecamatan Candisari". ENCLOSURE Volume 7 No. 1 Maret 2008 hlm. 38-49 Jurnal Ilmiah Perancangan Kota dan Permukiman. Melalui http://eprints.undip.ac.id/20145/1/5.pdf (15-08-2016).

UNFPA Indonesia. 2014. Monografh Series No.1 Indonesia On The Threshold Of Population Ageing. Jakarta: UNFPA Indonesia. 